\title{
ISU TERORISME DAN STIGMATISASI TERHADAP PONDOK PESANTREN
}

\author{
(Meluruskan Kesalahpahaman terhadap Pondok Pesantren) \\ Oleb: Amir Mu'allim*
}

\section{Abstract}

The terrorism issue has very popular in the beginning of 3 th millennium, especially after $9^{\text {th }}$ September 2001 tragedy. After this tragedy, western states, especially USA accused every Islamic institution as terrorist in the world. This stigma is also directed to pondok pesantren as one of Islamic education institution in Indonesia. It is caused by two factors, first, there were some terrorists bave studied in pondok pesantren and second, there subject of jibad in pondok pesantren. But their action is not pondok pesantren teaching. Pondok pesantren curriculum does not teach terror, because pesantren is the place for Islamic generation to learn about religion, Islamic values, akhlakul karimah to form them to be virtuous generation, both for themself and for society. Terror which done by person from pesantren is as reaction for western terror and attacking to many moslem countries i.e. Afgbanistan, Iraq, Palestine, Chechnya, etc.

a)

اشتهرت العملية الإرهاية في مستهل ألفية الثالثة، وبالمخصوص بعل حادئة WTC في الملادى مشر من

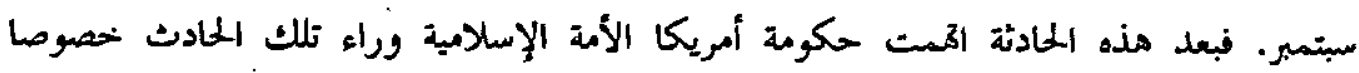

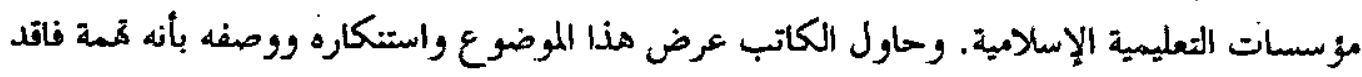

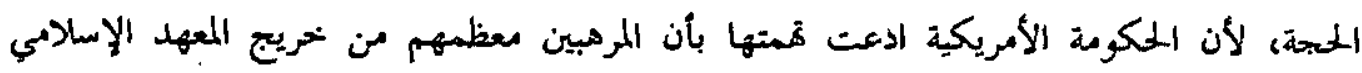

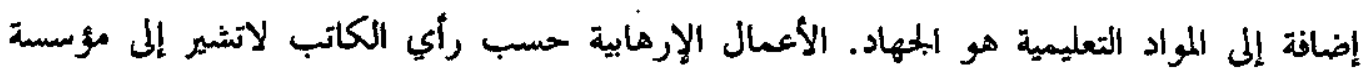

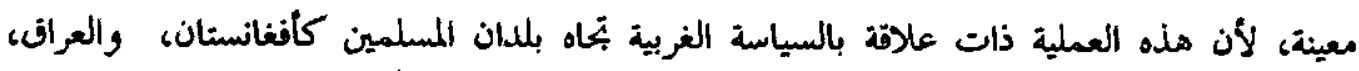
والثيشان و فلسنطين وغير ذلك.

Keywords: isu terorisme, stigmatisasi, kesalabpahaman dan pondok pesantren.

* Guru Besar Hukum Islam dan Direktur Magistet Studi Islam Universitas Islam Indonesia, tinggal di Yogyakarta. e-mail: amit_msi@yahoo.com 


\section{A. Pendabuluan}

Pondok pesantren merupakan institusi pendidikan agama Islam yang sangat fungsional. Pesantren mampu memberi jawaban terhadap berbagai permasalah yang dihadapi masyarakat setta mampu mempertahankan eksistensi meskipun perubahan zaman berjalan dengan pesat. Bukan hanya itu, sebagai lembaga pendidikan, pondok pesantren mampu menyesuaikan diri dengan betbagai situasi dan kondisi. Penyesuaian diri ini adalah keikutsertaan sepenuhnya dalam atus pengembangan ilmu pengetahuan (modern) dan teknologi.

Seiring dengan petkembangan zaman, tantangan yang harus dihadapi ternyata semakin kompleks dan berat. Pusaran arus globalisasi menuntut pesantten, bukan hanya mempertahankan eksistensi, akan tetapi juga mengembangkan diri dan lingkungannya. Perkembangan isu-isu modern yang terkadang menyeret nama Islam kedalamnya, secara otomatis juga menyeret pondok pesantren sebagai lembaga pendidikan agama Islam yang tertua di Indonesia. Hal yang paling nyata adalah isu terorisme. Ketika isu terorisme dikait-kaitkan dengan kalangan Islam, maka institusi pesantren secara spontan juga dikaitkan dengan isu yang menarik mayotitas perhatian global, khusunya negara-negara Barat ini.

Jihad yang masuk bab dalam salah satu kajian fikih dan dipelajati di pondok pesantren dituduh sebagai pemicu betbagai aksi kekerasan atau tindakan tetot yang akhir-akhir int kian meningkat. Berbagai tuduhan miring dilemparkan ke institusi pencetak intelektual sholeh ini. Di antara tuduhan yang dilemparkan oleh negara Barat adalah pesantren sebagai sarang teroris, tempat persemaian teroris dan tuduhan negatif lainnya. Akibat tuduhan ini, semua gerak-gerik pondok pesantren selalu dicurigai, bahkan diawasi oleh inteljen. Tulisan singkat ini akan mencoba menepis stigmatisasi dan meluruskan kesalahpahaman terhadap pondok pesantren, khusunya terkait dengan isu teotisme. Selain itu juga membuka fakta siapa sebenarnya penyebab, pemicu dan pelaku tindakan teror yang semakin sering terjadi, meskipun dunia telah mengumumkan "perang terbuka" dengan kalangan teroris.

\section{B. Pondok Pesantren dalam Lintas Sejarah}

Pesantren merupakan lembaga studi Islam yang mempunyai nilai historis terhadap getakan sosial keagamaan. ${ }^{1}$ Lembaga ini merupakan lembaga pendidikan Islam tertua di Indonesia. Maka wajarlah apabila banyak kalangan yang menyebutnya sebagai "Bapak" pendidikan Islam di negara yang mayoritas penduduknya umat Islam ini. Pondok pesantren lahir karena adanya turitutan dan kebutuhan masyarakat,

${ }^{1}$ Lihat Zamakhsyari Dhofir (1994), Tradisi Pesantren: Studi tentang Pantangan Hidup Kyai, Jakarta: LP3ES; Kamaruzzaman Bustamam-Ahmad (2002), Islam Historis: Dinamitea Studi Islam di Indonesia, Yogyakarta: Galang Press, pp. 65-82. 
dimana pada zaman dahulu belum ada lembaga pendidikan formal; dan meskipun ada hanya dapat diikuti oleh kelompok-kelompok tertentu.

Karena adanya tuntutan dari umat ini, maka pondok pesantren selalu menjaga hubungan yang harmonis dengan masyarakat di sekitarnya sehingga kehadirannya di tengah-tengah masyarakat tidak menjadi asing. Dalam waktu yang sama segala aktivitasnya juga mendapat dukungan dan apresiasi dari masyarakat sekitar. ${ }^{2}$

Menurut pendataan Departemen Agama, pada tahun 1948-1985 diperoleh keterangan bahwa pesantren tertua didirikan pada tahun 1062 di Pamekasan Madura, dengan nama pesantren Jan Tampes II. ${ }^{3}$ Namun keterangan ini kurang meyakinkan, karena apabila ada pesantren Jan Tampes II maka ada pesantren Jan Tampes I yang lebih tua. ${ }^{4}$

Menurut sumber lain, pondok pesantren lahir sejak munculnya masyaraka Islam di Nusantara pada abad XIII. Seiring dengan perjalanan waktu, pendidikan pondok pesantren mengalami perkembangan. Lembaga ini semakin berkembanng secara cepat dengan adanya sikap non-koperatif ulama terhadap kebijakan "Politik Etis" pemerintah kolonial Belanda pada akahir abad XIX. Sikap non-koperatif dan sillent Oppsition para ulama itu kemudian ditunjukkan dengan mendirikan pesantren di daetah-daerah yang jauh dari kota untuk menghindati intervensi pemerintah kolonial setta memberikan kesempatan kepada rakyat yang belum memperoleh pendidikan. ${ }^{5}$ Pada masa penjajahan kolonial Belanda ini, pondok pesantren mendapat. tekanan yang cukup berat. ${ }^{6}$

Proklamasi kemerdekaan Bangsa Indonesia membawa angin segar bagi perkembangan pendidikan Islam, khusunya pesantren, karena sudah tidak ada lagi tekanan dari pihak asing untuk menjalankan dan mengembangkan pendidikan agama Islam. Pada masa ini pesantren mulai menata diri dan memapankan posisinya sebaga lembaga pendidikan agama Islam.

Menurut Abdurrahman Wahid sebenarnya sejak tahun 1920-an Pondok Pesantren mulai mengadakan eksperimentasi dengan mendirikan sekolah-sekolah di lingkungan pesantren sendiri. Kemudian pada tahun 1930-an, pondok pesantren sudah mampu memperlihatkan kurikulum. Puncaknya kempanan sekolah agama

${ }^{2}$ Hasan Basri (2001), "Pesantren: Karakteristik dan Unsur-Unsur Kelembagaan" dalam Sejarah Pertumbuhan dan Perkembangan Lembaga-lembaga Pendidikan Islam di Indonesia, Jakarta: Grasindo, p. 101.

${ }^{3}$ Hasbullah (1996), Kapita Selekta Pendidikan Islam, Jakarta: Raja Grafindo, p. 41.

' Dwi Priyanto (2006), "Inovasi Kurikulum Pesantren (Memproyeksikan Model Pendidikan Alternatif Masa Depan)" dalam Mabda' Jurna/ Studi Islant dan Budaya, Punwokerto: Pusat Penelitian dan Pengabdian pada Masyarakat (P3M) Sekolah Tinggi Agama Islam Negeri Purwokerto, p. 22.

${ }^{5}$ M. Sulthon Mashud dan Moh. Khusnurdilo (2003), Manajemen Pondok Pesantren, Jakarta: Diva Pustaka, pp. 1-2.

'Abdurrahman Mas'ud (2004), Intelektual Pesantren, Yogyakarta: LKiS, p. 77. 
negeri di lingkungan pondok pesantren terjadi sekitar tahun 1960-an, juga terjadi percobaan isolasi di berbagai pondok pesantren. ${ }^{7}$

Memasuki era 1970-an pondok Pesantren mengalami perubahan sangat signifikan. Perubahan dan perkembangan ini bisa dilihat dari dua sudut pandang. Pertama, pesantren mengalami perkembangan kuantitas luar biasa dan menakjubkan, baik di wilayah ruial (pedesaan) sub-urban (pinggiran kota), maupun urban (perkotaan). Data Departemen Agama menyebutkan pada tahun 1977 jumlah pondok pesantren masih sekitar 4.195 dengan jumlah santri sekitar 677.394 orang. Kemudian pada tahun 1985 jumlah ini meningkat cukup drastis di mana jumlah pondok pesantren mencapai 6.239 dengan jumlah santri mencapai 1.084 .801 orang. Pada tahun 1997, jumlah ini melonjak menjadi 9:388 dengan jumlah santri 1.770.768 orang. Data Depag tahun 2001 menujukkan jumlah pondok pesantren di Indonesia mencapai 11.312 buah dengan jumlah santri 2.737 .805 orang. $^{8}$

Perkembangan kedua menyangkut penyelenggaraan pendidikan. Sejak tahun 1970-an bentuk-bentuk pendidikan yang diselenggarakan di Pondok Pesantren sudah sangat bervatiasi. Bentuk-bentuk ini dapat dikalsifikasikan menjadi empat tipe, yaitu: 1) Pondok pesantren yang menyelenggarakan pendidikan formal dengan menerapkan kurikulum nasional, baik yang hanya memiliki sekolah keagamaan maupun yang juga memiliki sekolah umum.

2) Pondok pesantren yang menyelenggarakan pendidikan keagamaan dalam bentuk madrasah dan mengajarkan ilmu-ilmu umum meskipun tidak menerapkan kurikulum nasional.

3) Pondok pesantren yang hanya mengajarkan ilmu-ilmu agama dalam bentuk Madrasah Diniyah (MD).

4) Pondok Pesantren yang hanya menjadi tempat melaksanakan pengajian.'

Dengan demikian jelas bahwa pondok pesantren tidak hanya bisa bettahan, akan tetapi juga berkembang dan menempati posisi penting dalam percaturan pendidikan di Indonesia. Dalam mengembangkan pola pendidikan dan mentransformasikan menjadi lembaga pendidikan Islam modern, nampaknya pondok pesantren tidak tergesa-gesa dan cukup berhati-hati. Hal ini tetlihat dari penerimaan dan penyesuaian pola pendidikan yang hanya dalam skala yang sangat terbatas, sebatas terhadap hal-hal yang mendukung komunitas pesantren itu sendiri. Azyumardi Azra berpendapat bahwa pesantren pada mulanya hanya rural based institution kemudian menjadi lembaga pendidikan urban, yaitu munculnya sejumlah pondok pesantren di

"Abdurrahman Wahid (1999), "Prolog" dalam Pondok Pesantren Masa Depan: Wacana Pemberdgiaan dan Transformasi Pesaitren, Bandung: Pustaka Hidayah, p. 20.

${ }^{8}$ M. Sulthon Mashud dan Moh. Khusnurdilo, op. cit., p. 4.

Ibid., p. 5. 
kota-kota. $^{10}$

\section{Sistem Pendidikakan Pondok Pesantren}

Pesantren merupakan institusi pendidikan yang melekat dalam perjalanan kehidupan bangsa Indonesia sejak beratus tahun lalu. Sehingga, Ki Hajar Dewantara pernah mencita-citakan model pesantren ini sebagai sistem pendidikan Indonesia, katena pesantren sudah melekat dalam kehidupan di Indonesia serta merupakan kteasi budaya Indonesia. ${ }^{11}$ Pondok pesantren adalah aset pendidikan bangsa Indonesia yang selama ini agak diabaikan. Selama ini, pondok pesantren cenderung dibiarkan berjalan sendiri dan kurang begitu diakomodir dalam sistem pendidikan nasional, padahal sumbangan yang diberikan oleh Pesantren terhadap pengembangan Sumber Daya Manusia (SDM) Indonesia sangat besar. Karakter khas pondok pesantren yang merakyat, metupakan potensi seharusnya senantiasa diperhatikan dan diberdayakan secata berkelanjutan dan terprogram.

Pendidikan pesantren memang unik dan eksklusif. Dalam banyak perspektif, pendidikan di pesantren selalu menampakkan wajah yang terkesan tradisional, klasik serta apa adanya. Namun tidak dipungkiri dengan citra wajah yang muncul seperti itu, justru tidak lapuk dimakan zaman, bahkan di tengah gempuran arus globalisasi yang kian menggila dan bedonisme masyarakat yang kian meningkat, pesantren tetap mampu memikat sebagai komunitas masyarakat untuk tetap dijadikan sebagai tempat menuntut ilmu. Karena itu, jika dilihat dengan teleskop antropologis, pesantren bisa dibaca dalam berbagai aspek. Sebagai lembaga pendidikan, namun di sisi lain pesantren juga bisa dibaca sebagai sebuah identitas masyarakat yang strategis. ${ }^{12}$

Sistem perididikan pesantren di Indonesia cukup antisipatif terhadap kebutuhan masyarakat, selain itu pendidikannya juga mudah menyesuaikan dengan sistem pendidikan yang ada. Hal ini terbukti dengan pengapdosian sistem pendidikan yang berlaku merupakan proses timbal balik antara pola pendidikan di pondok pesantren dengan sistem pendidikan "umum" yang ada di luar pesantren. Meskipun menurut Nurcholish Madjid pesantren tidak mengenal istilah kurikulum, terutama pada masa prakemerdekaan, tetapi pesantren telah memberikan materi pendidikan yang cukup terprogram dan bahkan memberikan materi keterampilan. Memang harus diakui, kebanyakan pesantren tidak merumuskan dasar dan tujuan pesantren secara eksplisit dalam bentuk kurikulum, karena tujuan pendidikan pesantren ditentukan

10 Azyumardi Azta (1997), "Kuantitas dan Perubahan" Pengantar Buku Nutcholish Madjid, Bilik-bilik Pesantren: Sebrab Pemikiran Islam di Indonesia, Jakarta: Paramadina, p. XXII. p. 121.

${ }^{11}$ Nurcholish Madjid (1997), Bilik-Bilik Pesantren: Sebuab Potret Perjalanan, Jakarta: Paramadina,

${ }^{12}$ Mahfudz Ridwan (2005), Mendorong Pesantren sebagai Agen Pendamping Perubaban di Masyarakat, Digital Library Responsible Development Intemational (RDI). 
oleh kiai, sesuai dengan perkembangan pesantren tersebut. ${ }^{13}$

Pondok pesantren selalu memodernisasi sistem pendidikannya dengan tidak hanya mengajarkan ilmu-ilmu agama saja, akan tetapi juga mengajatkan matapelajaran yang ada dalam sistem pendidikan nasional. Dengan sistem pendidikan seperti ini maka pondok pesantren tidak hanya dapat bertahan, akan tetapi juga berkembang dan tidak pernah tertinggal oleh perkembangan zaman. Maka wajar apabila pesantren mampu mencetak banyak pemikir Islam Indonesia. Melihat perkembangan zaman yang semakin pesat, maka pesantren segera menyesuaikan diri dengan melakukan proses urbanisasi intelektual. Santri-santri yang tadinya hanya membaca kitab kuning, memakai sarung, peci, kemudian metambah "dunia lain" dengan menjadi seotang pemuda yang membaca kitab putih, memakai jeans dan gaya parlente, menulis menggunakan computer, dan tidur di kantor-kantor yang serba beton, maka wajar apabila ada yang menyebutnya dengan gejala "santri kota."14

Ketika ada wacana Islam liberal, pondok pesantren juga tidak mau tinggal diam, para santri menggeluti pemikiran Islam kontemporer yang kekiri-kirian. Mereka juga mulai merambah dan menekuni teori-teori sosial. Bahkan santri-santri atau mahasiswa yang pernah mengenyam pendidikan pesantren tampak mempunyai pandangan keislaman yang cukup berani jika dibandingkan dengan mereka yang tidak pernah belajar di pesantren. Hal ini tidak terlepas dari petan civitas akademika pesantren yang mulai membuka diri dengan mengenal literatur-literatur tentang wacana Islam kontemporer seperti; Syed Hussein Nashr, Fazlurrahman, Hasan Hanafi, Nashr Hamid Abu Zaid dan intelektual muslim kontemporer lainnya.

Dari sini kita dapat melihat bahwa pendidikan pondok pesantren cukup tetbuka dan tidak monoton atau kolot. Pesantren dapat menyesuaikan dan sekaligus membawa dirinya dalam segala situasi dan kondisi. Namun dernikian perubahan zaman tidak dapat memudarkan eksistensi dan bahkan dijadikan moment untuk mengembangkan pola pendidikan, sehingga melahirkan pemikir-pemikir Islam yang siap terjun di masyatakat dalam kondisi dan situasi apapun. Satu hal yang perlu ditekankan adalah bahwa pendidikan pesantren tidak pernah mengajarkan atau memberikan "kurikulum terorisme" kepada santri atau civitas akademika pesantren dan juga tidak pernah menggunakan cara-cata kekerasan untuk menyelesaikan permasalahan yang dihadapi, sebagaimana yang dituduhkan beberapa kalangan terkait dengan isu terorisme. Mereka diberi pelajaran untuk menyelesaikan permasalahan dengan cara-cara yang elegan dan beradab. Karena di pesantren selalu diajarkan membangun kesalehan spiritual yang harus ditransformasikan dalam masyarakat atau kesalehan sosial. Walaupun ada santri yang melakukan kekerasan,

${ }^{13}$ Nurcholish Madjid, op. cit., p. 59.

${ }^{1+}$ Lihat Mlochamad Sodik (2000), Gejolak Santri Kota: Aktivis Mada NU Merambah Jalan Lain, Yogyakarta: Tiara Wacana. 
ini bukanlah hasil atau produk pendidikan pesantren, tetapi karena adanya faktor lain yang tidakpernah terungkapkan.

\section{Dampak Isu Terorisme terhadap Pondok Pesantren}

Menyikapi isu terorisme yang akhir-akhir ini semakin marak, masyarakat dunia yang terpolatisasi kepada Timur dan Batat, mempunyai perspektif yang berbeda antara yang satu dengan yang lain. Perbedaan perspektif ini cukup wajar, karena memang belum ada definisi baku yang disepakati tentang terorisme. Menurut sebagian pakar, istilah terorisme merupakan suatu terminologi yang ambigu dan kabur. Michael Kinsley, seorang kolomnis yang menulis dalam Washington Post, 5 Oktober 2001, mengatakan bahwa usaha mendefinisikan terorisme adalah sesuatu yang mustahil. Namun yang jelas, yang diterima dan dugunakan sekarang adalah definisi yang dibuat oleh penguasa dan kekuasaan serta mampu memaksakan kehendaknya dengan segala kemampuannya, baik militer, politik, ekonomi, teknologi, dan kekuatan budayanya. Dalam hal ini adalah Amerika Serikat, yang mengaku sebagai polisi dunia, dan celakanya, dalam mindset mereka terorisme selalu betkaitan dengan umat Islam.

Meskipun belum ada definisi yang komprehensif dan disepakati namun banyak kalangan yang menjuruskan berbagai tindakan teror kepada Islam. Tuduhan terorisme kepada Islam ini sangat berpengaruh juga terhadap eksistensi dan reputasi pondok pesantren yang notabene lembaga pendidikan Islam. Persepsi negatif tethadap Islam terkait dengan isu terorisme ini merupakan salah satu bukti bahwa tindakan teror yang akhir-akhir ini terjadi diklaim bermotif ideologi atau agama.

Sebenarnya tindakan terotisme ini dilakukan dengan berbagai motif. Menurut Loudewijk F. Paulus terorisme mempunyai berbagai motif yang secara garis besar dapat diklasifikasikan menjadi tiga kategoti: rasional, psikologi dan budaya yang kemudian dapat dijabarkan lebih luas. Namun motif yang sering muncul di kancah dunia modern ini, terotisme yang dilakukan untuk mempertahankan atau memperluas daerah jajahan seperti yang dilakukan oleh tentara-tentara Israel terhadap pejuang Palestina. Selain itu, terorisme dalam bentuk usaha untuk memisahkan diri dari pemerintahan yang sah (sepatatis). Contohnya adalah IRA (Irish Republica Army) yang dengan segala bentuk kegiatannya dicap sebagai teroris oleh pemerintah Inggris. Motif lain adalah usaha untuk melakukan protes terhadap sistem sosial yang betlaku seperti Brigade Merah Italia, yang bertujuan untuk membebaskan Italia dari kaum kapitalis multinasionalis. Namun akhir-akhir ini terorisme selalu dikaitkan dengan motif agama. ${ }^{15}$

Tinta merah aksi terorisme terus menerus tertoreh dalam lembaran sejarah dunia modern, Tiger di Srilanka, Takfir wal-Hijtah di Mesir, Baader-Meinhof di

${ }^{15}$ Loudewijk F. Paulus (2000), Terorisme, Buletin Balitbang Dephan. htm.www.dephan.go.id 
Jerman, Red Brigdes di Italia, Action Directe di Prancis, Irish Republican Army di Inggris, Tupak Amaru di Peru, Aum Shinri Kyo di Jepang dan yang terakhir adalah kelompok Al-Qaidah yang berbasis di Afghanistan. ${ }^{16}$ Kalau dilihat secara obyektif, berbagai aksi teror yang akhir-akhir ini sering terjadi bukan atas dasar agama, namun bermotif politik, ekonomi dan kepentingan lain.

Bagaimanapun juga pondok pesantren sudah terlanjur mendapat setigma dan implikasi yang sangat merugikan eksistensi dan reputasinya sebagai lembaga pendidikan agama Islam. Salah satu implikasi yang paling dirasakan pondok pesantren adalah semua gerak-gerik pondok pesantren selalu dicurigai karena takut akan menimbulkan kekerasan atau tindakan teror. Bahkan wakil presiden, Yusuf Kalla menginstruksikan kepada aparat agar mengawasi pondok pesantren. Instruksi ini diterapkan terhadap sebagian pondok pesantren yang ditengarai melahirkan santrisantri yang petnah melakukan tindakan teror.

Pengawasan terhadap pesantren merupakan pesanan dati pihak asing yang merasa kepentingannya terancam oleh teroris. Padahal alasan ini tidaklah tepat apabila dijadikan dalih untuk melakukan pengawasan terhadap aktivitas pondok pesantren, karena pondok pesantrean merupakan lembaga pendidikan agama Islam, bukan tempat pendidikan teror. ${ }^{17}$ Pengawasan pondok pesantren di Indonesia juga pernah dilakukan oleh pemerintahan kolonial pada masa penjajahan. Dalam Reglement op bet beleid der regeering van Nederlansch-Indie (sejenis UUD Hindia Belanda) 1855, pasal $124,{ }^{18}$ disebutkan bahwa raja, bupati, dan ulama diberi wewenang untuk mengawasi sekolah-sekolah agama Islam. Pasal ini yang diasumsikan bahwa PB IX dapat menghidupkan kembali Pesantren Jamsaren sepanjang raja dapat melakukan pengawasan tethadap pesantren itu dan tidak melakukan tindakan-tindakan yang bettentangan dengan peraturan gubernur jenderal: ${ }^{19}$

Kecurigaan yang berlebihan terhadap aktivitas pondok pesantren ini menjadikannya seolah-olah pesantren memang menjadi sarang teroris. Meskipun tuduhan pesantren sebagai sarang teroris tidak membuat pesantren ditingalkan masyarakat, namun tuduhan ini menimbulkan pandangan negatif terhadap pendidikan sebagian pondok pesantren di Indonesia, di antaranya pondok pesantren Al Mukmin Ngruki Sukoharjo dan Al Islam Tenggulun Solokuto Lamongan. Memang

${ }^{16}$ Alwi Shihab (2004), Membedah Islam di Barat: Menepis Tudingan Meluruskan Kesalabpahaman, Jakarta: PT. Gramedia Pustaka Utama, p. 5.

${ }^{17}$ Wahjoetomo (1997), Perguruan Tinggi Pesantren, Jakarta: LP3S, p. 18.

${ }^{13}$ Indie 1905, No. 550, pasal 1, dikemukakan bahwa siapa saja yang hendak memberi pengajaran agama Islam diwajibkan memiliki izin tertulis dari bupati atau patih dengan mencantumkan sifat pengajaran tersebut.

${ }^{19}$ Munculnya kebijakan politik etis mendorong pendidikan pribumi guna mengisi jabatan bitokrasi administrasi pemerintahan dalam kerangka desentralisasi pemerintahan di Hindia Belanda, yang pada puncaknya akan diditikan Volksraad, sebagai proto-parlemen kolonial. 
harus diakui, sebagaimana hasil penelitian yang dilakukan oleh Puslitbang dan Diklat Keagamaan Departemen Agama RI, dua pesantren ini mengembangkan pengajaran salafi atau tradisional. Salafi adalah pemurnian ajaran agama Islam dengan menerima dan mengamalkan syariat Islam secara utuh. Aliran ini cenderung radikal dalam menegakkan pemahamannya. ${ }^{20} \mathrm{Namun}$ demikian kedua pondok pesantren ini tidak pernah mengajarkan kekerasan kepada para santrinya.

\section{E. Menepis Tudingan Negatif terbadap Pondok Pesantren tentang Isu Terorisme}

Menurut Whittaker, terorisme dapat muncul karena ajaran agama atau motivasi agama. Sentimen agama sering menjadi salah satu penyebab radikalisme dan terorisme. ${ }^{21}$ Namun demikian aksi terorisme yang marak akhir-akhir ini sebenarnya bukan dilatarbelakangi oleh ajaran agama. Aksi kekerasan tersebut muncul lebih mengarah pada reaksi oleh kelompok yang frustasi dan kecewa terhadap ketidakadilan global dan tindakan negara-negara Barat, khususnya Amerika yang selalu melakukan teror dan mendukung Israel dalam melakukan teror terhadap para pejuang Palestina. Ketika AS sebagai lambang kapitalisme dan sekularisme mendominasi peradaban Barat, karakteristik benturan kepentingan tidak lagi dibangun atas konsep teologis, dan ideologis. Konflik peradaban lebih dibangun atas kepentingan politik, ekonomi dan pertahanan.

Adanya kepentingan-kepentingan Barat di atas sering mendatangkan reaksi tegas atau bahkan keras dari kalangan Islam. Namun reaksi yang merupakan sebuah usaha untuk melakukan perlawanan ini sering diartikan sebagai tindakan teror dan selanjutnya dijadikan sasaran tembak untuk melemparkan tuduhan bahwa Islam adalah agama kekerasan, penindasan anti HAM dan berbagai tuduhan-tuduhan negatif lain. Dalam hal ini pondok pesantren sebagai lembaga pendidikan agama Islam terkena dampaknya. Pondok pesantren dianggap sebagai tempat pengkadetan teroris.

Setidaknya ada dua faktor yang melatarbelakangi stigmatisasi tethadap pondok pesantren ini; pertama, adanya oknum-oknum pesantren yang terbukti melakukan tindakan teror. Para pelaku pemboman di Bali, Jakarta dan daetah-daerah lain yang kebetulan sebagian pelakunya adalah santri, membawa citra buruk pondok pesantren di mata masyarakat Indonesia dan bahkan masyarakat internasional. Mereka mencurigai pesantren telah menjadi ajang penyemaian teroris. Bahkan, ada pihak yang mengusulkan supaya kurikulum pondok pesantren diubah. Pemerintah AS melaui George Bush juga pernah meminta pemerintah Arab Saudi untuk

${ }^{20} \mathrm{H}$. Baudet dan I.J. Brugmans (1987), "Balans van Beleid, Terugblik op de Laatste halve eeuw van Neder-landsch-Indie" dalam Politik Etis dan Revolusi Kemerdekaan, Jakatta: YOI., pp. 238-253.

${ }^{21}$ Suara Merdeka, Senin 24 Oktober 2005. 
menghilangkan konsep jihad dari ajaran Islam. ${ }^{22}$

Memang harus diakui bahwa para pelaku ledakan mulai dari WTC, sampai yang terjadi di Indonesia, bom Madrid, bom London dan lain-lain yang berasal dari kalangan Islam fundamentalis. Untuk peledakan bom di Indonesia memang ada yang dilakukan oleh beberapa santri. Namun apa yang mereka lakukan hanyalah sebagai reaksi terhadap kebrutalan AS dan sekutu-sekutunya dalam percaturan politik internasional dan bukan tindakan teror yang muncul di ruang hampa.

Kedua, adanya konsep jihad dalam Islam yang juga dipelajari di pondok pesantren. Memang ada beberapa kalangan yang salah dalam mengartikan jihad ini. Jihad diartikan sebagai aktivitas mengangkat senjata dan membunuh musuh dalam kondidsi apapun. Pemahaman semacam ini merupakan pemahaman yang salah dan inilah yang menimbulkan tuduhan bahwa kekerasan yang dilakukan oleh sebagian umat Islam merupakan ajatan Islam itu sendiri. Padahal, terjadinya tindak kekerasan yang mengatasnamakan jihad ini akibat adanya misunderstanding tadi. Islam sama sekali tidak membenarkan kekerasan, anarkisme dan terorisme. Dalam kurikulum pendidikan pondok pesantren sama sekali tidak diajarkan kekerasan, apalagi tindakan teror. Jihad yang dipelajari di pondok pesantren sangat berbeda dengan terorisme. Jihad adalah salah satu metode dakwah sebagai pembelaan diri terhadap umat Islam, yaitu untuk mempertahankan agama, diri, harta dan kehormatan. Hal ini tentunya sangat jauh betbeda dengan teror yang merupakan tindakan untuk menakut-nakuti, melakukan kekerasan sehingga menimbulkan korban harta atau jiwa. Islam memerintahkan umatnya untuk teguh membela hak milik dan tanah airnya. Pembelaan terhadap tanah air dan hak milik juga diakui secara resmi oleh undangundang internasional. Dengan kata lain, pembelaar terhadap tanah air dan hak milik bukanlah sebuah bentuk terorisme.

Selain itu, dalam realitas penerapan jihad jauh dari yang dibayangkan masyarakat pada umumnya. Bab yang membahas masalah jihad, terdapat tuntunan bagaimana berjihad yang benar, termasuk adab dalam peperangan, memperlakukan tawanan perang, aturan memperlakukan wilayah musuh, sampai aturan tentang tampasan perang. Dalam bab ini juga diajarkan bahwa dalam suatu peperangan tidak boleh membunuh anak-anak dan wanita dan aturan-aturan lain dalam perang. Akan tetapi muncul kekerasan yang dilakukan oleh oknum yang berasal dari kalangan pondok pesantren.

Diakui atau tidak, tuduhan yang dilemparkan terhadap Islam, khususnya pondok pesantren berkaitan dengan terorisme merupakan rekayasa yang dilakukan oleh media massa yang berafiliasi dengan pemerintah Amerika dan rezim Zionis. Sesungguhnya, pendidikan di.pondok pesantren berlandaskan pada spiritualisme

${ }^{22}$ Whittaker (2000), Terorisme: Understanding Global Tbreat, New York: Longman London, pp. 91 - 
dan moral, serta menentang terorisme dan kekerasan. Pondok pesantren yang merupakan tempat pendidikan yang berlandaskan pada ajaran Islam tidak mengajarkan pembunuhan terhadap orang yang tidak berdosa.

Fakta di lapangan menunjukkan bahwa ada paradoks mengenai isu terorisme dan wacana fundamentalisme. Dalam hal ini AS menerapkan standar ganda dalam politik internasional. Di satu sisi ia menjadi "panglima" perang melawan terotisme, selalu mencurigai dan menekan kalangan fundamentalis Islam, namun di sisi lain ia mendukung tindakan terotisme dan AS sendiri adalah teorisme negara.

AS juga dengan terang-terangan mendukung Istael yang jelas-jelas melakukan teror terhadap pera pejuang Palestina. Kebrutalan usaha-usaha Israel untuk menekan Palestina pernah dikemukakan oleh menteri pertahanan Yitzhak Rabin. Pada 19 Januari 1988, dia menyiarkan kebijaksanaan "patah tulang" dengan mengatakan bahwa Israel akan menggunakan "kekerasan, kekuatan dan pukulan-pukulan" untuk menekan para pejuang Palestina. Perdana Menteri Yitzhak Shamir juga pernah menyatakan bahwa tugasnya adalah menciptakan kembali benteng rasa takut antara orang-orang Palestina dan militer Istael. Menurutnya; yang penting adalah menyebarkan rasa takut akan kematian pada orang-orang Arab di wilayah-wilayah Israel untuk mencegah mereka agar tidak menyerang lagi. ${ }^{23}$ Perlu diketahui juga bahwa satu-satunya negara yang telah menebarkan tetor ke seluruh dinia adalah Amerika Serikat. AS juga satu-satunya negara di dunia yang dikritik oleh Pengadilan Internasional atas tindakan terotismenya. ${ }^{24}$

Noam Cosmky, pakar linguistik pada the Massachussets Institute of Technology mengatakan "we should not forget that the US itself is a leading terrorist state". Dia juga menyatakan bahwa pengeboman atas Afghanistan (oleh pasukan sekutu pimpinan AS) adalah kejahatan lebih besar dari pada teror 11 September dan AS adalah terdakwa negara teroris. Edward S. Herman, guru besar di Universitas Penslyvania, dalam bukunya The Real Teror Network, mengungkap fakta-fakta keganjilan kebijakan anti-terorisme AS. Selama ini AS menjadi pendukung rezim-rezim "teroris" Garcia di Gautamala, Pinochet di Chili dan rezim Apartheid di Afrika Selatan. ${ }^{25}$

AS dan para sekutunya bertindak diskriminatif terhadap kelompok masyarakat tertentu sebagai bentuk ketidakadilan global yang terjadi di banyak Negara, khususnya Negara muslim. Yang paling nyata adalah invasi AS terhadap Afganistan dan Irak yang diwarnai oleh penyiksaan terhdap para tahanan; pembunuhan anak-

${ }_{3}^{23}$ Muhammad Imarah (2003), Fi Fiqh al-Muwäjahab bain al-Gharb wa al-Isiâm, Cairo: Maktabah alSyuruq al-Dauliah, pp. 88-89.

${ }^{34}$ Paul Findley (1995), Diplomasi Munafik Ala Yabudi; Mengungkap Fakta Hubungan AS-Israel, Bandung: Mizan, p. 123

${ }^{23}$ Juhaya S. Praja, op. cit., p. 36 
anak yang tak berdosa ${ }^{26}$ dan keketasan yang dilakukan oleh tentata Istael tethadap para pejuang Palestina. Ketidakadilan dan standar ganda yang diterapkan oleh AS inilah yang memupuk rasa kebencian kalangan Islam terhadap Barat, terutama Amerika.

Apa yang dilakukan Israel terhadap para pejuang Palestina jelas-jelas tindakan teror, namun AS, sebagai negara yang mengaku panglima perang terhadap terorisme, negara yang mengaku penjung nilai-nilai HAM dan kebebasan, bungkam seribu bahasa seakan mengamini tindak kejahatan kemanusiaan yang dilakukan oleh militer Israel.

Di sisi lain ada wacana Islam fundamentalis atau Islam militan yang sudah lekat dengan berbagai aksi teror sehingga mereka menjadi musuh utama Barat, terutama AS. Media masa menggunakan momentum 11 September untuk menciptakan citra bahwa semua umat muslim adalah teroris dan agama Islam adalah - agama yang mengajarkan kekerasan. Samuel P. Huntington, ketika berdialog dengan Anthonny Gidden, pada musim semi 2003 mengatakan bahwa militan Islam adalah ancaman bagi Barat. Oleh karena itu mereka harus diperangi. Satu strategi yang memungkinkan adalah dilakukannya serangan dini (preemptive-strike) terhadap ancaman serius dan mendesak. ${ }^{27}$

Rasa kebencian dan frustasi ini diekspresikan dengan berbagai tindak kekerasan seperti peledakan WTC, bom bunuh diri dan berbagai peledakan yang bertujuan untuk melakukan perlawanan terhadap hegemoni AS, imprealisme Barat dan kapitalisme global. Meskipun demikian pelaku-pelaku kekerasan yang umumnya dari kalangan Islam fundamentalis ini beralasan bahwa apa yang mereka lakukan merupakan jihad di jalan Allah. Para pelaku teror di Indonesia yang sebagian berasal dari kalangan pondok pesantren mengaku bahwa mereka melakukan tindak kekerasan dengan meledakkan berbagai fasilitas fital sebagai jihad dan ungkapan kebencian terhadap AS dan sekutunya seperti Australia.

\section{F. Penutup}

Utaian di atas menunjukkan bahwa tuduhan negatif terhadap pondok pesantren

${ }^{26}$ Edwatd S. Herman (1982), The Real Teror Network: Terrorisme in Fact in Propaganda, Boston: South End Press, pp. 76-79. Catatan ini mungkin cukup untuk menjadi bukti kebrutalan AS dan sekutusekutunya tethadap anak-anak yang berdosa: According to the latest UNICEF report (2006), in 2004 the under5 infant mortality was 122,000 in Occupied Irag, 359,000 in Occupied Afghanistan and 1,000 in the occupying country Australia (noting that in 2004 the populations of these countries were 28.1 million, 28.6 million and 19.9 million, respectiveby). About 1,300 wider-5 year old infants will bave died in Ocapied Iraq and Afghanistan on Christmas Day alone and 0.5 million will die in the coming year due to non-provision by the US-led Coalition of lifepreserving requisites demanded by the Geneva Conventions.

${ }^{27}$ Samuel P. Huntington (1996), The Clash of Civilization and the Remaking of Wrorld Order, New Yotk: Touchtone Books, p. 209. 
sebagai satang teroris sama sekali tidak berdasar. Tuduhan ini muncul hanya sekedar reaksi terhadap bebetapa tindakan teror yang kebetulan dilakukan oleh pihak yang pernah belajat di pondok pesantren. Pondok pesantren sama sekali tidak mengajarkan tindak kekerasan, apalagi mencetak terotis. Pondok pesantten sebagai lembaga pendidikan Islam selalu mengajarkan dan membentuk pribadi yang shaleh, baik dalam hal spiritual maupun dalam lingkungan sosial. Sebenarnya apa yang mereka lakukan hanya sekedat teaksi terhadap tindakan teror yang ditebar oleh negara-negara Barat, khusunya AS terhadap umat Islam seperti Palestina, Irak, Afghanistan dan negara yang berpenduduk muslim lainnya.

\section{DAFTAR PUSTAKA}

Abdurrahman Mas'ud (2004), Intelektual Pesantren, Yogyakarta: LKiS.

Abdurrahman Wahid (1999), "Prolog" dalam Pondok Pesantren Masa Depan: Wacana

Pemberdayaan dan Transformasi Pesantren, Bandung: Pustaka Hidayah.

Baudet, H. dan I.J. Brugmans (1987), "Balans van Beleid, Terugblik op de Laatste halve eeuw van Neder-landsch-Indie" dalam Politik Etis dan Revolusi Kemerdekaan, Jakarta: YOI.

Dwi Priyanto (2006), "Inovasi Kurikulum Pesantren (Memproyeksikan Model Pendidikan Alternatif Masa Depan)" dalam Mabda' Jurnal Studi Islam dan Budaya, Purwokerto: Pusat Penelitian dan Pengabdian pada Masyarakat (P3M) Sekolah Tinggi Agama Islam Negeri Purwokerto.

Findley, Paul (1995), Diplomasi Munafik Ala Yabudi; Mengungkap Fakta Hubungan AS-Israel (terj), Bandung: Mizan.

Hasan Basri (2001), "Pesantren: Karakteristik dan Unsur-Unsur Kelembagaan” dalam

Sejarah Pertumbuban dan Perkembangan Lembaga-lembaga Pendidikan Islam di Indonesia, Jakarta: Grasindo.

Hasbullah (1996), Kapita Selekta Pendidikan Islam, Jakarta: Raja Grafindo.

Herman, Edward S. (1982), The Real Teror Network: Terrorisme in Fact in Propaganda,

Boston: South End Press.

Huntington, Samuel P. (1996), The Clash of Citrilization and the Remaking of World Order, New York: Touchtone Books:

Kamaruzzaman Bustamam-Ahmad (2002), Islam Historis: Dinamika Studi Islam di Indonesia, Yogyakarta: Galang Press.

M. Sulthon Mashhud dan Moh. Khusnurdilo (2003), Manajemen Pondok Pesantren, Jakarta: Diva Pustaka. 